International Journal of Current Advanced Research

ISSN: O: 2319-6475, ISSN: P: 2319 - 6505, Impact Factor: SJIF: 5.438

Available Online at www.journalijcar.org

Volume 6; Issue 3; March 2017; Page No. 2334-2337

DOI: http://dx.doi.org/10.24327/ijcar.2017.2337.0003

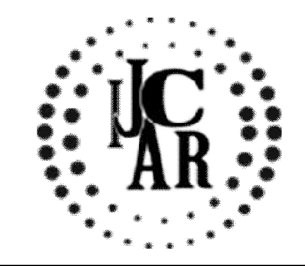

Research Article

\title{
BIODIVERSITY AND TOURISM A CASE STUDY OF RAKCHHAM-CHHITKUL WILDLIFE SANCTUARY IN TRANS-HIMALAYAN BASPA (SANGLA) VALLEY, DISTRICT KINNAUR, HIMACHAL PRADESH, INDIA
}

\author{
*Rakesh Kumar Negi
}

Government College, Sunni, Shimla, H.P. India

\begin{tabular}{|c|c|}
\hline 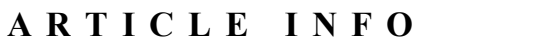 & $A B S T R A C T$ \\
\hline Article History: & \multirow{8}{*}{$\begin{array}{l}\text { Biodiversity is the variety of life on the earth including all organisms, species and } \\
\text { populations; the genetic variations among these and their complex assemblages of } \\
\text { communities and ecosystem. It is the essence and manifestation of evolutionary history of } \\
\text { life on earth and species is the most conspicuous form of the biodiversity. Tourism is a } \\
\text { social, cultural and economic phenomenon which entails the movement of people to } \\
\text { countries or places outside their usual environment for personal or professional purpose. } \\
\text { Biodiversity and tourism share a symbiotic relationship which can be negative as well as } \\
\text { positive. However with areas of unique natural beauty attracting large numbers of visitors, } \\
\text { biodiversity is one of the greatest assets of the tourism-its natural capital. Rakchham- } \\
\text { Chhitkul Wildlife Sanctuary in Trans-Himalayan Baspa (Sangla) Valley, District Kinnaur } \\
\text { is rich in biodiversity and cultural diversity which attracts a large number of tourists every } \\
\text { year. However excessive anthropogenic pressures, mainly driven by tourism in this area is } \\
\text { causing habitat modification and destructions in recent times resulting in loss of } \\
\text { biodiversity of the fragile ecosystem of this sanctuary drastically. }\end{array}$} \\
\hline Received $10^{\text {th }}$ December, 2016 & \\
\hline Received in revised form $7^{\text {th }}$ January, 2017 & \\
\hline Accepted $11^{\text {th }}$ February, 2017 & \\
\hline Published online $28^{\text {th }}$ March, 2017 & \\
\hline Key words: & \\
\hline Biodiversity, Eco-Tourism, & \\
\hline Trans-himalaya Habitat frag & \\
\hline
\end{tabular}

Copyright $\subseteq 2017$ Rakesh Kumar Negi. This is an open access article distributed under the Creative Commons Attribution License, which permits unrestricted use, distribution, and reproduction in any medium, provided the original work is properly cited.

\section{INTRODUCTION}

Biodiversity is the variety and variability of all forms of life on earth that plays a great role in human existence (Borokini et al., 2010; Antofie, 2011). Despite the fact that biodiversity remains the basis for resources we depend for our survival, the full diversity and richness of living resources have not been fully explored and understood. As the basis for all ecosystem services, and the foundation for truly sustainable development, biodiversity plays fundamental roles in maintaining and enhancing the well being of the world population.

Tourism is a social, cultural and economic phenomenon which entails the movement of people to countries or places outside their usual environment for personal or business /professional purpose. With areas of unique natural beauty attracting large numbers of visitors, biodiversity is one of the greatest assets of the tourism-its natural capital, and fundamental to its long term growth. Every year millions of people fulfil their urge to see and experience the wonders of nature by getting out of their usual environment and moving

*Corresponding author: Rakesh Kumar Negi

Government College, Sunni, Shimla, H.P. India across the world as tourists. In 2013, about 1087 million international tourists travelled the world generating 1.4 trillion US dollar (UNTWO, 2013). However biodiversity and tourism share a symbiotic relationship which can be negative as well as positive.

Himachal Pradesh is mainly a hilly state lying in northwest Himalayas with a total geographic area of 55,673 sq km comprising $1.7 \%$ of total geographic area of the country. The population of the state is $68,56,509$ which accounts for only $0.57 \%$ of country population. The physiography of Himachal Pradesh is mostly mountainous with elevations ranging from 350 to 6,975 metres above mean sea level thus presenting varied landscape features ranging from tropical to alpine setups. The varied climatic conditions ranging from tropical to arctic has bestowed the state with a rich array of biodiversity. There is a pronounced dominance of Palaearctic and endemic animals above tree line $(3000 \mathrm{~m})$, and largely Oriental and some Palaearctic and Ethiopian elements at lower and middle altitudes. Himachal Pradesh has only $1.7 \%$ of total geographical area of the country but shares more than $7 \%$ of the total faunal diversity of the country. There are 2,542 faunal species as compared to 92,279 species of the country. Invertebrates constitute $88.4 \%$ and vertebrates $11.6 \%$ of the fauna of the state. There are 111 mammalian species forming $25 \%$ of the country, 447 species of birds (36\%), 55 
reptiles (11\%), 17 amphibians (5\%) and 104 species of fishes (4\%), reported from the state (Sharma and Saikia, 2009).

This varied geography offers several pristine destinations that can be explored and enjoyed by tourists. The state owing to its natural heritage ranks among the top tourist destination in the country-both for national and international visitors. Every year several tourists from different regions of world come and find blissful rendezvous in the lap of such a beautiful destination. Recent estimates place the number of visitors at about 160 lakh visitors- more than twice the state population. (Department of Forest Govt.of H.P 2016). Thus tourism has been recognized as one of the most important sectors of the economy of the state and a potential engine of its economic growth. The contribution of the tourism sector to the state Gross Domestic Product (GDP) is 7.5\% (Economic Survey of Himachal Pradesh 2014-15). The tribal districts of Kinnaur and Lahaul\& Spiti are blessed with unique climatic geospatial gradients which have endowed these areas with a rich biodiversity consisting of some unique and threatened species. The natural vegetation of Kinnaur district can be classified into 29 types which belong to Himalayan moist and dry temperate forest, sub-alpine forest, dry and moist alpine scrub and meadows. Alpine meadows cover large areas above the tree line (usually above $3300 \mathrm{~m}$ ). Below the tree line, thick coniferous forests are dominated by Cedrus deodara. The Pinus gerardiana (Neoza pine) dominated forest occupies large area in the dry zone upto tree line in Kinnaur.
This species occurs mostly in Kinnaur district in the state of Himachal Pradesh (Chawla et al., 2012). More than half of the total area of Kinnaur $(51.92 \%)$ is covered by bare rocks and perpetual snow. The forest covers $10.24 \%$ area, grassland covers $31.04 \%$ and scrubland covers $2.95 \%$ of the total area of district. The landscape and unique culture of these districts attract tourist worldwide. In 2014, kinnaur district alone was visited by 28581 visitors including 2084 foreigners (Department of Environment, Science \& Technology, Govt. of H.P 2015)

\section{Study Area}

Present study has been conducted in Rakchham- Chhitkul Wildlife Sanctuary located in the Baspa (Sangla) valley covering an area of about $304 \mathrm{Km}^{2}$ lying between geocoordinates of latitude $31^{0} 14^{\prime} 22^{\prime \prime} \mathrm{N}-31^{0} 28^{\prime} 37^{\prime} \mathrm{N}$ and longitudes $78^{0} 17^{\prime} 31^{\prime \prime} \mathrm{E}-78^{0} 31^{\prime} 30^{\prime \prime} \mathrm{E}$ in the northeast corner of Kinnaur, a tribal district of Himachal Pradesh, India (Fig. 1). The Baspa river originates near the Indo-Tibet border forms this valley from Chhitkul to Karchham where it joins the Sutlej river. The valley is characterized by rugged, precipitous peaks covered by perpetual snow cover (Deota et al., 2011) which are the parts of Great Himalayan range and Dhauladhar ranges. The mountain ranges on the right bank of Baspa river form the part of Great Himalayan range while those on the left bank form the Dhauladhar ranges separating

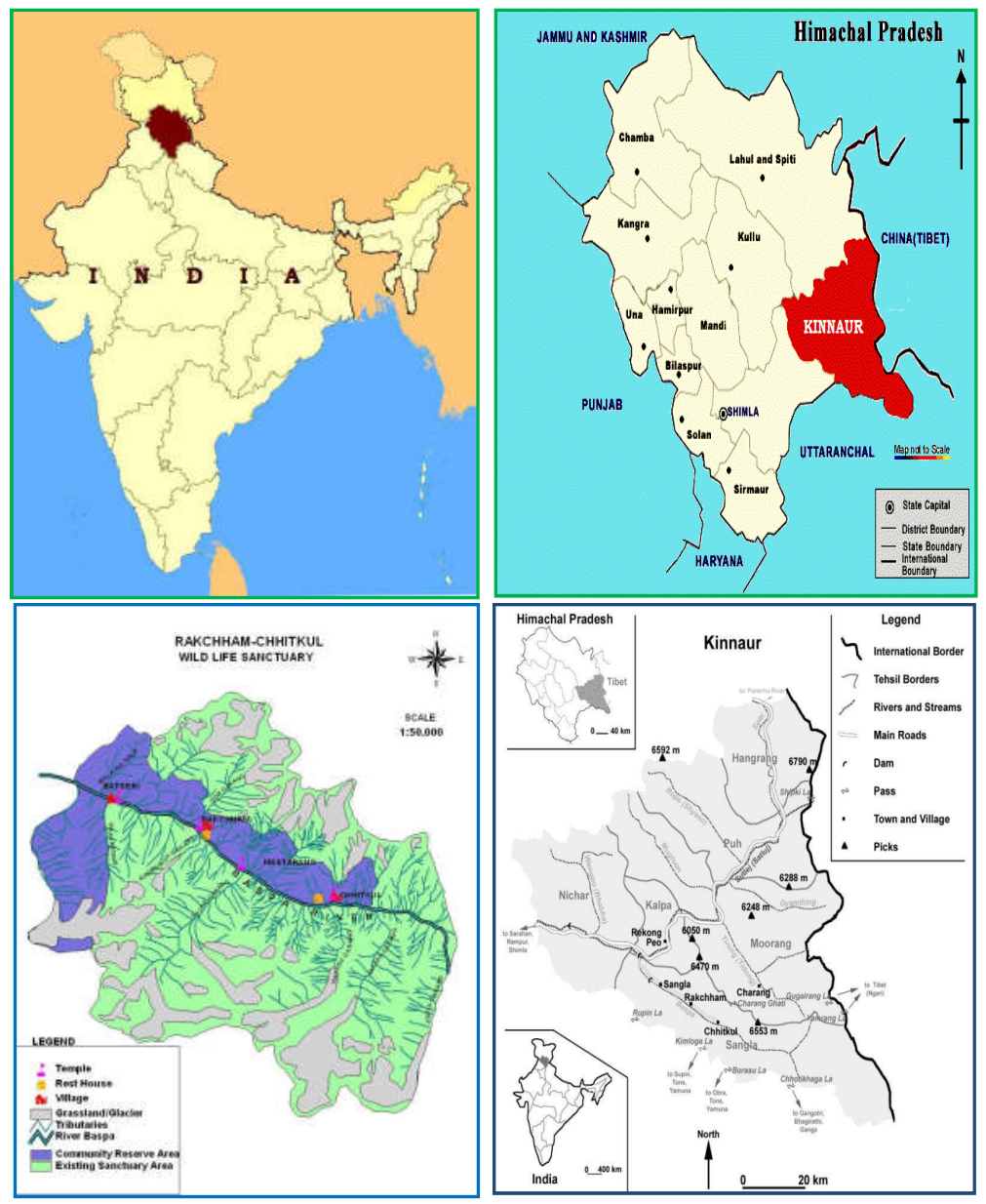

Fig.1 Map of Baspa valley, the study area in District Kinnaur, Himachal Pradesh, India (Source: mapsofindia.com and diagrammatic map of Baspa Valley). 
The forest type of this sanctuary includes Lower Western Himalayan Temperate Forest, Upper Western Himalayan Temperate Forest and Sub-Alpine Birch-Fir Forest. The sanctuary area is fed with numerous snow-fed perennial and Baspa valley from Uttarakhand state of India and parts of Shimla district of the Himachal Pradesh. The altitude of Baspa valley ranges from 2,800 masl to 5,486 masl. The temperature varying from $-15^{\circ} \mathrm{C}$ to $18^{\circ} \mathrm{C}$, mean rainfall 463 $\mathrm{mm}$ and annual snowfall $1,130 \mathrm{~mm}$. seasonal streams. The Govind Pashu Vihar a wildlife sanctuary of Uttarakhand is adjacent to Rakchham-Chhitkul sanctuary and on its eastern boundary lays the Tibetan plateau of China. The valley is famous for many of its passes connecting it with Tibet and Shimla District of Himachal Pradesh.

\section{MATERIAL AND METHODS}

The study area is present at the cusp of Great Himalayan and Trans Himalayan range thus presenting vast altitudinal, geological and ecological gradient. The left bank of river Baspa is bestowed with thick forests of Tosh, Spruce, Blue pine, deodar etc. The forest of the area is divided into different zones like forests of lower areas dominated by lower level fir like Tosh extending from Sangla to Khrogla (3000$3300 \mathrm{~m}$ ), a little above these the forests are dominated by Deodar extending from Khrogla to Mustarang (3300-3500m) and the higher reaches of the forest dominated by Blue pine extending from Mustarang to Nagasti (3500-4000m) beyond which lies the large tract of alpine meadows (4000-5500m). This sanctuary is famous for the tract of Betula (Bhojpatra) tree beyond $3000 \mathrm{~m}$ till the tree line. Most of the villages are situated on the right bank except village Batseri. The study was conducted through the survey method. This study is completely based on knowledge obtained by primary information and secondary information. The primary data was obtained by visiting the area. These primary data was supported by secondary information mainly through various journals, articles, news paper reports and books.

\section{RESULTS \& DISCUSSION}

Present study revealed that the sanctuary located in the salubrious climes of Baspa Valley in Kinnaur district is rich in biodiversity and home to a number of flora and fauna species. It harbours a total of 322 plant species belonging to 70 families and 162 genera. Out of these there are 127 medicinal plants (Verma and Kapoor 2013). As of faunal diversity it harbours a total of 104 species of vertebrates, which includes 02 species of fishes, 01 of amphibians, 05 of reptiles, 73 birds, and 23 species of mammals. It has been recorded that the birds were the most dominant vertebrates, followed by mammals, reptiles and fishes, while amphibian was represented least by a single species. It has been recorded that these 104 species belonged to 17 orders, 41 families and 33 genera. The birds and mammals were represented by 09 and 05 orders respectively, while all other vertebrate classes were represented by 01 order each. The family-wise analysis of data revealed that bird were represented by 24 families, mammals by 11 families, reptiles by 4 families, and amphibian and fishes were restricted to a single family each. Further analysis of data showed that birds were represented by 52 genera, mammals by 20 , reptiles by 5 , fishes by 2 genera and amphibians by a single genus (Negi and Banyal 2016). A study on the vascular plants of the district Kinnaur revealed the presence of 893 taxa (viz., species, subspecies and varieties) belonging to 881 species of angiosperms and gymnosperms distributed among 102 families and 433 genera, and 30 species of pteridophytes. It was found that family Compositae is by far the most species rich family with 122 species, followed by Poaceae (69), Rosaceae (58), Leguminosae (49) and Lamiaceae (38). Among the genera, Artemisia was the most diverse genus with 19 species, followed by Potentilla (14), Saussurea (13), Polygonum (11), Astragalus (10), Lonicera (10) and Nepeta (10). Similar to other regions in the western Himalayan range, family-togenera ratio was 1:4.25 and the genera-to-species ratio was $1: 2.04$. Out of 893 taxa, there were 606 herb species, 63 trees, 108 shrubs, 28 climbers, 67 graminoids and 21 sedges and rushes (Chawla et al., 2012). Similiarly the total number of plant species in Ranikanda area of the sanctuary was 102 belonging to 31 families and 66 genera. The dominant families were Asteraceae, Rosaceae, Ploygonaceae, Lamiaceae, Scrophulariaceae and Ranunculaceae. Among the 5 species of shrubs, Juniperus indica was the dominant species having maximum density (Verma and Kapoor 2014). Most of the Mammalian species of the study area are given protection under different Schedules of Wildlife (Protection) Act, 1972 and also listed in IUCN Red List of Threatened Species and CITES (Convention in Trade of Endangered Species). A total of six mammalian species reported from the study area were found to be declared threatened, therefore, placed under different catogories by IUCN. Of these Semnopithecus ajax, Uncia uncia and Moschus chrysogaster are placed in Endangered, Ursus thibetanus as Vulnerable while Panthera pardus and Alticola roylei are listed as Near Threatened (Negi and Banyal 2015)

The tourism sector in the area is although in its nascent stage, but the growth is robust. There were about 25 private guest houses operational in the area besides five guest houses under various departments of the Government of Himachal Pradesh. The private owned guest houses were present in all the villages but their number was more in lower altitudinal area like Sangla. The Government Guest Houses were present at least one in every village. Apart from these there were about nine tent houses also operational in the area which provides the camping facility to the visitors. In addition to this the newly introduced scheme of Home Stay by government is also being pursued by the local people under this scheme a tourist is not only able to enjoy a clean and affordable place for stay in the home of local people but also gets an opportunity to learn about local customs, traditions and cuisine.

However it has been proved throughout world that tourism destroys tourism. Excessive anthropogenic pressures, mainly driven by tourism in this area is causing habitat modification and destructions in recent times resulting in loss of biodiversity of the fragile ecosystem of this sanctuary drastically. It was observed that there was a sudden and steep increase in the construction of a number of new guest houses. As has been seen in cases of Shimla and Manali the haphazard growth of buildings and concrete structures, has deteriorated the sheen of these beautiful destinations. In addition many negative effects also exist, such as the transformation of traditional cultural symbols into commodities to sell to visitors. The visitors are offered angling activity by some 
operators which is going to be detrimental to the fish fauna of this area.

Based upon the present study, some of the measures for efficient conservation of biodiversity as well as development of tourism in Rakchham-Chhitkul wildlife sanctuary area in District Kinnaur are like encouragement to ecotourism, enumeration of diversity and status of wildlife species, development of ex-situ measures for threatened wildlife diversity conservation, development of site/location specific guidelines for propagation of threatened species, proper impact assessment and monitoring of detrimental effects of commercial activities like tourism in the area, involvement of local stakeholders and shepherds in conservation and maintenance of the fragile ecosystem of the Sanctuary, discourage the construction of new river valley projects and proper regulation of tourist inflow particularly during summer months have been proposed.

\section{References}

Antofie, M. (2011). Current political commitments' challenges for ex situ conservation of plant genetic resources for food and agriculture, Analele Universit at, ii din Oradea-Fascicula Biologie, vol. 18, pp. 157-163.

Borokini, T.I., Okere, A.U., Giwa, A.O., Daramola, B.O. and Odofin, W.T. (2010). Biodiversity and conservation of plant genetic resources in Field Gene-bank of the National Centre for Genetic Resources and Biotechnology, Ibadan, Nigeria, The. International Journal of Biodiversity and Conservation, vol. 2, pp.37-50.

Chawla A, Om Parkash, Sharma V, Rajkumar S, Brij Lal, Gopichand, Singh R D and Thukral A K(2012). Vascular plants, Kinnaur, Himachal Pradesh, India Check List Journal of Species list and its Distribution 8(3): 321-348, 2012 ISSN 1809-127X (available at www.checklist.org.br)

Deota, B. S., Trivedi, Y. N., Kulkarni, A. V., Bahuguna, I. M. and Rathore, B. P. (2011). RS and GIS in mapping of geomorphic records and understanding the local controls of glacial retreat from the Baspa Valley, Himachal Pradesh, India. Current Science, 100(10).
Department of Environment, Science \& Technology, Govt. Of H.P(2015). Environment Master Plan Infrastructrue Sector, 2015

Department of Forest Govt.of H.P (2016) Revised EcoTourism Policy 2016.

Negi R. K. and Banyal, H.S., (2015). Status, Diversity and Ecology of Mammals of Trans - Himalayan RakchhamChhitkul Wildlife Sanctuary in Baspa (Sangla) Valley, District Kinnaur, Himachal Pradesh, India IOSR Journal of Pharmacy and Biological Sciences (IOSR-JPBS) eISSN: 2278-3008, p-ISSN:2319-7676. Volume 10, Issue 4 Ver. V (Jul-Aug.2015), PP 06-12 www.iosrjournals.org DOI: $10.9790 / 3008-10450612$

Negi R. K. and Banyal, H.S., (2016) A Preliminary Study on the Species Composition of Vertebrates in RakchhamChhitkul Wildlife Sanctuary in Trans-Himalayan Baspa (Sangla) Valley, District Kinnaur, Himachal Pradesh, India IOSR Journal of Pharmacy and Biological Sciences (IOSR-JPBS) e-ISSN:2278-3008, p-ISSN:23197676. Volume 11, Issue 6 Ver. IV (Nov. - Dec.2016), PP 51-60 www.iosrjournals.org DOI: 10.9790/30081106045160

Sharma D.K., and Saikia U., (2009). Faunal Diversity of Simbalbara Wildlife Sanctuary, Conservation Area Series, Zoo. Surv. India.,41:103-118.

UNWTO-Understanding Tourism: Basic Glossary http://me dia.unwto.org/en/content/ understanding-tourism-basicglossary

Verma R.K and Kapoor K.S (2013). Rakchham-Chhitkul Wildlife Sanctuary Kinnaur, Himachal Pradesh:An Appraisal to its Floristic Wealth. HFRI/Book/039-2013 pp 144

Verma R.K and Kapoor K.S (2014). Status of Plant Diversity in Alpine Area of Rakchham- Chitkul Wildlife Sanctuary of District Kinnaur, Himachal Pradesh Biological Forum an International Journal 6(1): 5-12(2014)

\section{Please cite this article in press as:}

Rakesh Kumar Negi (2017), Biodiversity and tourism a case study of rakchham-chhitkul wildlife sanctuary in trans-himalayan baspa (sangla) valley, district kinnaur, himachal pradesh, india, International Journal of Current Advanced Research, 6(3), pp. 2334-2337. http://dx.doi.org/10.24327/ijcar.2017.2337.0003 